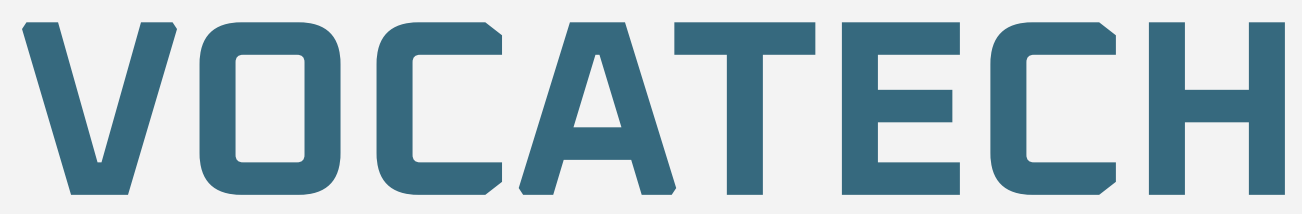

VOCATIONAL EDUCATION AND TECHNOLGY JOURNAL

Biannual

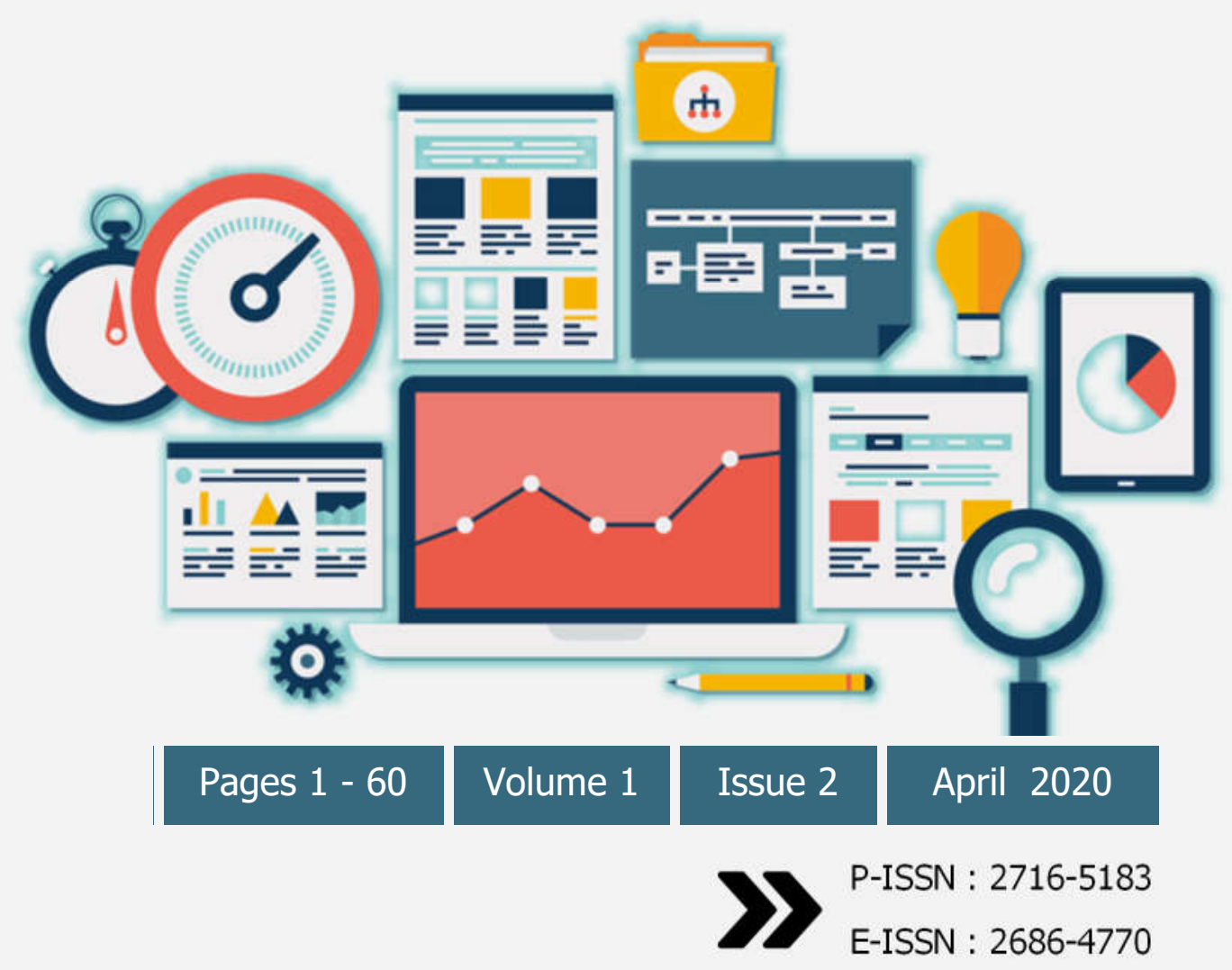

Published By: Unit Penelitian, Pengabdian Masyarakat dan Penjaminan Mutu Akademi Komunitas Negeri Aceh Barat

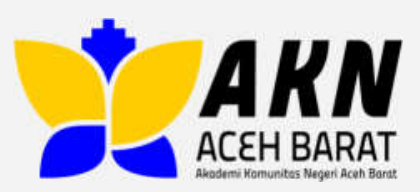




\section{P-ISSN : 2716-5183 \\ E-ISSN : 2686-4770

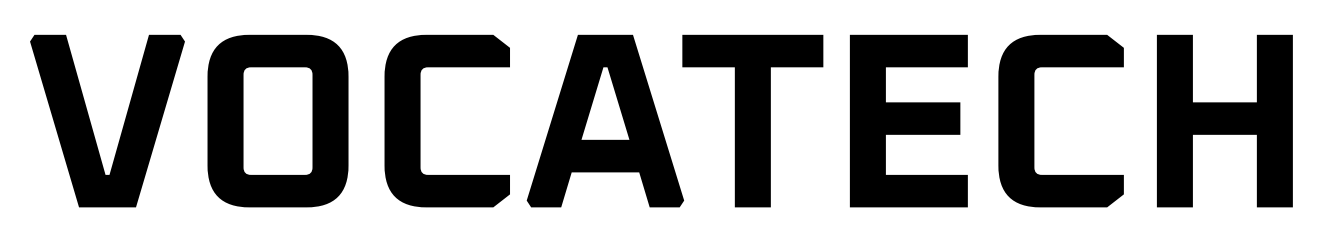

VOCATIONAL EDUCATION AND TECHNOLGY JOURNAL

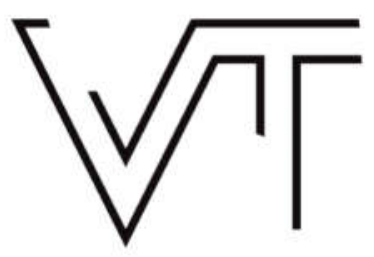

\section{Editorial Team}

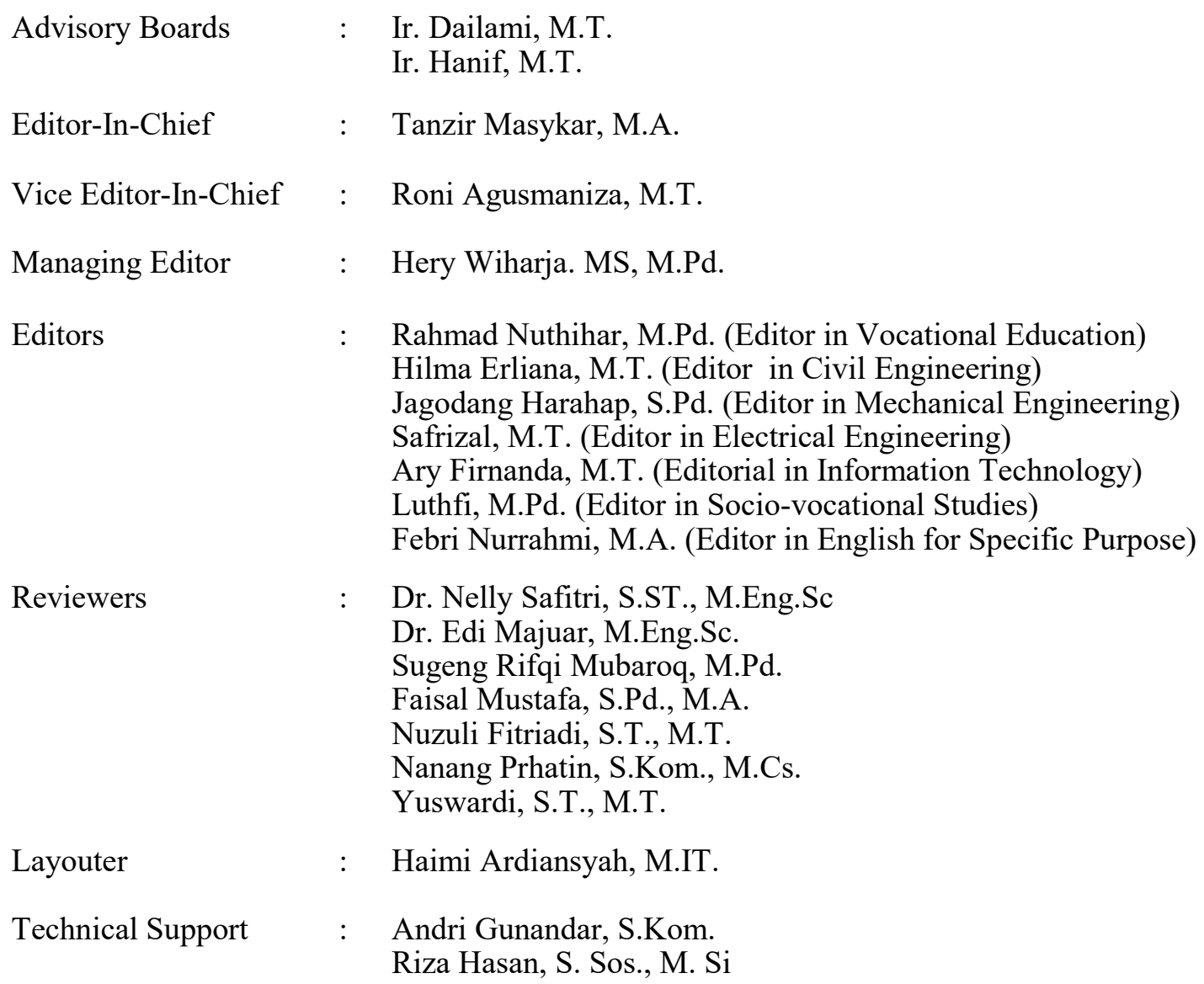

\section{Alamat Redaksi (Journal Address)}

Unit Penelitian, Pengabdian Masyarakat dan Penjaminan Mutu

Akademi Komunitas Negeri Aceh Barat

Komplek STTU Alue Peunyareng, Ujong Tanoh Darat, Meureubo, Kabupaten Aceh Barat, Aceh 23615, Indonesia

Website: http://ojs.aknacehbarat.ac.id/index.php/vocatech/index

Email:vocatech@akanacehbarat.ac.id 


\section{(2) \\ E-ISSN : 2686-4770

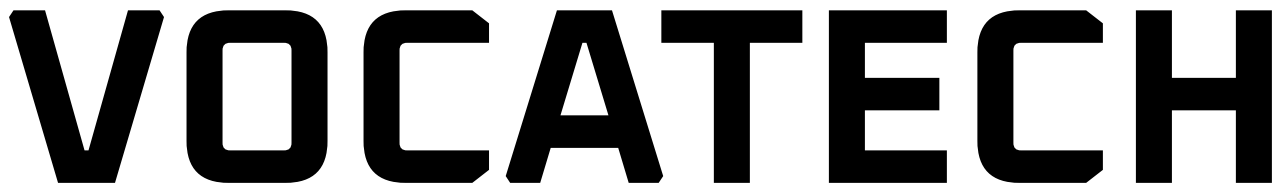 \\ VOCATIONAL EDUCATION AND TECHNOLGY JOURNAL}

\section{DAFTAR ISI (TABLE OF CONTENT)}

Pengaruh $R O E, D E R$, dan EPS Terhadap Harga Saham pada Emiten Syariah Sektor Barang

Konsumsi di BEI

—Dwi Meilvinasvita, Safaruddin, Yuliana—-

Penerapan General English dan English For Specific Purposes di Perguruan Tinggi Khususnya pada Pendidikan Vokasi

\section{—Rena Juliana, Reni Juliani-}

Pengaruh Penggunaan Kapasitor Bank pada Penyulang Kota di Pt. PLN (Persero) Rayon

Meulaboh Kota

-Haimi Ardiansyah-

Desain Alat Uji Impak Jatuh Bebas untuk Pengujian Baja Struktur

—Dailami, Hamdami, Samsul Bahri-

Analisis Kinerja Angkutan Kota dalam Provinsi di Provinsi Aceh Berdasarkan Pendekatan Load

Factor

—Ruhdi Faisal, Cut Mutiawati , Alfi Salmannur-

Klasifikasi Kematangan Buah Tomat dengan Variasi Model Warna Menggunakan Support Vector

Machine

\section{-Nica Astrianda-}

Implementasi Algoritma K-Mean dalam Pengelompokan Data Kecelakaan di Kabupaten Kediri

—Adimas Ketut Nalendra, M. Mujiono, Rafika Akhsani, Adiguna Sasama Wahyu U.- 
VOCATECH: Vocational Education and Technology Journal 1, 2 (2020): 1-13

Website: http://ojs.aknacehbarat.ac.id/index.php/vocatech/index

ISSN 2716-5183 (online) ISSN 2686-4770 (print)

\title{
PENGARUH ROE, DER, DAN EPS TERHADAP HARGA SAHAM PADA EMITEN SYARIAH SEKTOR BARANG KONSUMSI DI BEI
}

\author{
Dwi Meilvinasvita* \\ Safaruddin \\ Yuliana \\ Politeknik Negeri Lhokseumawe, Aceh
}

\begin{abstract}
Return On Equity (ROE), Deb to Equity Ratio (DER), and Earning Per Share (EPS) are some financial ratios that are used to analyze a company's performance effectively and efficiently. The positive company performance will encourage investors to be stimulated by placing funds through ownership of shares in its. The research sample uses purposive sampling method. The sample are 24 consumer goods sector companies that listed on Indonesia Stock Exchange (BEI) 2013 - 2017 with secondary data of annual financial reports. This study discusses about effected these ratios to the price of sharia shares so that it will contribute to analysis and decision making of investors and improvements of company in the future. By using multiple linear analysis methods the results show that simultaneously ROE, DER and EPS have significant effect on stock prices. Partially, ROE and EPS have significant effect, while DER ratio has not significant effect on stock prices. Therefor, Islamic issuers should maintain their performance, especially in profitability. The achivement of company profits is the main indicators to interest investors. It will affect the price of islamic stocks to rise and have positive prospect.
\end{abstract}

Keywords:

Financial Ratio, Investor, Indonesia Stock Exchange, Islamic Issuer

\begin{abstract}
Abstrak
Return On Equity (ROE), Deb to Equity Ratio (DER), dan Earning Per Share (EPS) merupakan beberapa rasio keuangan yang digunakan untuk melihat kinerja sebuah perusahaan secara efektif dan efisien. Kinerja perusahaan yang positif akan mendorong investor terstimulasi menempatkan dana melalui kepemilikan saham pada perusahaan tersebut. Penarikan sampel penelitian menggunakan purposive sampling. Sampel yang digunakan adalah 24 emiten syariah sektor industri barang konsumsi yang ada di Bursa Efek Indonesia (BEI) periode 2013 hingga 2017 dengan sumber data sekunder berupa laporan keuangan tahunan. Penelitian ini membahas sejauh mana rasio-rasio keuangan dari emiten syariah tersebut mempengaruhi harga saham sehingga diharapkan akan memberikan kontribusi bagi analisis dan pengambilan keputusan investor ke depannya dalam berinvestasi dan perbaikan kinerja perusahaan di masa akan datang. Dengan menggunakan metode analisis linear berganda hasil penelitian secara simultan menunjukkan ROE, DER dan EPS berpengaruh signifikan terhadap harga saham. Sementara itu, hasil uji parsial menunjukkan bahwa hanya ROE dan EPS yang berpengaruh signifkan, sedangkan rasio DER tidak berpengaruh signifikan terhadap harga saham. Oleh karena itu, emiten-emiten syariah harus mempertahankan kinerja perusahaan khususnya dalam menghasilkan laba. Pencapaian laba perusahaan menjadi indikator utama ketertarikan investor dalam berinvestasi yang akan mempengaruhi harga saham syariah menjadi naik dan memiliki prospek positif.
\end{abstract}

Kata Kunci:

Rasio Keuangan, Investor, Bursa Efek Indonesia, Emiten Syariah

Received: 3 March 2020 ; Revised: 27 March, 2020 ; Accepted: 30 March, 2020

DOI: https://doi.org/10.38038/vocatech.v1i2.23

Citation in APA Style: Meilvinasvita, D., Safaruddin, \& Yuliana. (2020). Pengaruh ROE, DER, dan EPS terhadap harga saham pada emiten syariah sektor barang konsumsi di BEI. VOCATECH: Vocational Education and Technology Journal, Vol. 1 (2), 1-13. 


\section{Corresponding author:}

Dwi Meilvinasvita, Program Studi Akuntansi Lembaga Keuangan Syariah, Politeknik Negeri Lhokseumawe, Jl. Banda Aceh-Medan Km. 280,3, Buketrata, Mesjid Punteut, Blang Mangat, Kota Lhokseumawe, Aceh 24301, Indonesia.

Email: dwimeilvinasvita@pnl.ac.id

\section{PENDAHULUAN}

Pasar modal adalah pertemuan antara pihak yang memiliki kelebihan dana dengan pihak yang membutuhkan dana dengan cara memperjualbelikan sekuritas (Eduardus, 2017:25). Sekuritas atau instrumen keuangan yang diperjualbelikan pada pasar modal adalah sekuritas yang umumnya memiliki jangka waktu lebih dari satu tahun dan terdiri dari saham, obligasi, dan reksa dana.

Di Indonesia, pasar untuk memperjualbelikan sekuritas disebut Bursa Efek Indonesia (BEI). BEI memiliki sembilan sektor usaha, salah satunya adalah sektor industri barang konsumsi (consumer goods). Sektor industri barang konsumsi memproduksi produk kebutuhan pokok sehari-hari yang biasa dibutuhkan, seperti makanan, minuman, rokok/tembakau, produk kebutuhan rumah tangga dan produk personal lainnya. Sektor ini relatif stabil dari fluktuatif ekonomi karena masyarakat selalu membutuhkan barang-barang konsumsi dan tidak mungkin mengurangi anggaran konsumsinya secara drastis meskipun dalam kondisi keuangan yang buruk.

Perusahaan-perusahaan yang bergerak di industri barang konsumsi ini juga memiliki ketertarikan untuk bersaing di pasar modal dengan menjual saham yang berbasis syariah. Hal ini seiring dengan kegiatan ekonomi syariah yang mengalami perkembangan dan diversifikasi instrumen keuangan berprinsip syariah.

Di BEI, jumlah saham emiten syariah yang listing semakin meningkat sebagai respons yang positif dari masyarakat yang sudah mulai menyadari tentang pentingnya seluruh kegiatan ekonomi dilakukan sesuai dengan prinsip syariah. Selain itu, pergerakan harga saham yang terjadi di BEI merupakan fenomena yang sangat menarik bagi investor untuk menganalisis kinerja masing-masing perusahaan sehingga para investor dapat menempatkan dana secara tepat dan mendapatkan keuntungan sesuai dengan yang diharapkan. Perkembangan harga saham syariah dapat dilihat pada grafik di bawah ini:

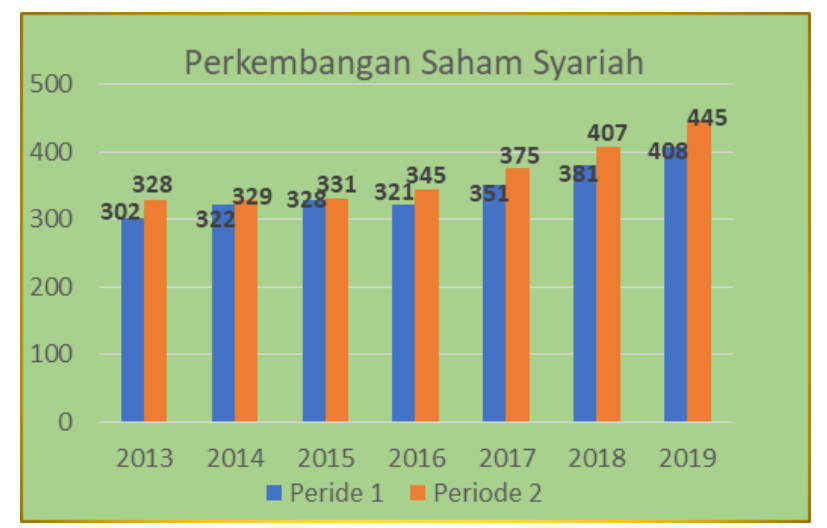

Gambar 1. Grafik Perkembangan Saham Syariah Sumber: www.ojk.go.id

Berdasarkan Gambar.1 dapat dilihat perkembangan saham syariah pada Daftar Efek Syariah sejak tahun 2013 sebanyak 302 emiten syariah hingga 2019 mengalami peningkatan menjadi 445 emiten syariah. Review daftar efek syariah ini dilakukan dua kali setiap tahun (dua periode), yaitu pada bulan Mei dan November. 
Investor menggunakan laporan keuangan sebagai sumber informasi utama analisis dalam keputusan investasinya. Analisis laporan keuangan tersebut dilakukan dengan menggunakan rasio-rasio keuangan perusahaan, di mana menurut (Kasmir, 2012:104) rasio keuangan adalah kegiatan membandingkan angka-angka yang ada dalam laporan keuangan dengan cara membagi satu angka dengan angka lainnya. Perbandingan dapat dilakukan antara satu komponen dengan komponen dalam satu laporan keuangan atau antar komponen yang ada di antara laporan keuangan.

ROE, DER dan EPS adalah beberapa rasio keuangan yang digunakan sebagai analisis untuk menilai pergerakan harga saham di pasar modal. Penelitian Valintino dan Sularto (2013) menunjukkan ROE, DER dan EPS serta dua variabel lainnya (ROA dan CR) secara bersama-sama (simultan) berpengaruh terhadap harga saham, sedangkan secara parsial ROE, EPS, dan ROA memiliki pengaruh signifikan, DER dan CR tidak memiliki pengaruh signifikan terhadap harga saham. Penelitian Abdullah, dkk. (2016) menunjukkan bahwa secara parsial variabel DER yang berpengaruh terhadap harga saham, sedangkan ROE dan EPS tidak berpengaruh terhadap harga saham. Sementara penelitian Alipudin dan Oktaviani (2016) menunjukkan bahwa secara parsial hanya EPS berpengaruh positif terhadap harga saham, sedangkan ROE dan DER tidak berpengaruh terhadap harga saham.

Selain penelitian pengaruh rasio keuangan terhadap harga saham secara umum, penelitian juga dilakukan pada saham syariah oleh Utami dan Darmawan (2018) yang menunjukkan bahwa secara parsial DER, ROA dan ROE tidak berpengaruh terhadap harga saham, sedangkan EPS dan MVA berpengaruh positif terhadap harga saham pada Indeks Saham Syariah Indonesia (ISSI).
Menurut Auliyah \& Hamzah (2006) dalam (Supadi dan Amin, 2016) saham syariah merupakan salah satu bentuk dari saham biasa yang memiliki karakteristik khusus berupa kontrol yang ketat dalam hal kehalalan ruang lingkup kegiatan usaha. Lebih lanjut Auliyah dan Hamzah mengungkapkan bahwa saham syariah juga memiliki tingkat return dan risiko yang sama seperti saham konvensional. Dengan demikian faktor fundamental seperti rasio keuangan dan faktor lainnya yang mempengaruhi harga saham secara umum juga dapat berlaku pada saham syariah.

Oleh karena itu, penulis tertarik meneliti pengaruh fluktuasi harga saham syariah karena instrumen ini masih baru dalam pasar keuangan. Adapun yang membedakan penelitian ini dengan beberapa penelitian sebelumnya adalah objek penelitian dilakukan terhadap emiten syariah yang termasuk dalam sektor barang konsumsi dengan periode kurun waktu yang berbeda. Penulis memilih beberapa rasio keuangan seperti ROE, DER dan EPS sebagai variabel yang mempengaruhi harga saham disebabkan variabel ini memiliki kecenderungan pengaruh yang lebih besar terhadap harga saham yang dibuktikan dari hasil-hasil penelitian sebelumnya.

Selain itu, kesuksesan investasi ditentukan oleh analisis kritis investor dalam memperhitungkan rasiorasio keuangan perusahaan yang dianggap layak atas dana investasi tersebut. Dengan mengetahui pengaruh ROE, DER dan EPS terhadap harga saham, diharapkan investor dapat meningkatkan analisis investasinya untuk mengurangi risiko yang mungkin timbul akibat investasi dan mendapatkan keuntungan yang lebih besar. Demikian pula bagi emiten-emiten syariah, pengaruh rasio keuangan terhadap harga saham pada penelitian ini dapat mendorong kinerja perusahaan menjadi lebih baik sehingga semakin diminati oleh investor, khususnya perbaikan pada 
variabel-variabel keuangan yang memiliki pengaruh signifikan terhadap harga saham.

\section{STUDI PUSTAKA}

\section{A. Saham Syariah}

Saham adalah tanda penyertaan modal seseorang atau pihak (badan usaha pada suatu perusahaan atau Perseroan Terbatas). Saham merupakan surat bukti penyertaan modal pada perusahaan dan dengan bukti tersebut pemegang saham berhak untuk mendapatkan bagian hasil dari usaha perusahaan (OJK, 2015:197). Sementara itu, saham syariah adalah surat bukti penyertaan modal pada suatu perusahaan dengan bukti penyertaan tersebut pemegang saham berhak untuk mendapatkan bagi hasil dari usaha perusahaan. Konsep penyertaan modal dengan hak bagi hasil ini merupakan konsep yang tidak bertentangan dengan prinsip syariah dengan bentuk kegiatan musyarakah atau syirkah (www.ojk.go.id).

Saham atau biasa disebut juga dengan efek merupakan salah satu instrumen yang diperjualbelikan di pasar modal. Saham syariah yang diperdagangkan di pasar modal syariah masuk dalam Daftar Efek Syariah. Menurut Peraturan Nomor II.K.1: Kriteria dan Penerbitan Daftar Efek Syariah oleh Bapepam-LK (www.ojk.go.id). Daftar Efek Syariah (DES) adalah kumpulan efek yang tidak bertentangan dengan prinsip-prinsip syariah di pasar modal yang ditetapkan oleh Bapepam dan LK atau diterbitkan oleh Pihak Penerbit DES. Adapun Daftar Efek Syariah yang diterbitkan meliputi dua kategori:

1. Efek yang diterbitkan oleh emiten atau perusahaan publik yang menyatakan kegiatan usaha serta pengelolaan usahanya dilakukan berdasarkan prinsip syariah sebagaimana tertuang dalam Anggaran Dasar emiten tersebut.

2. Efek yang diterbitkan oleh emiten atau perusahaan publik yang tidak menyatakan bahwa kegiatan usaha serta cara pengelolaan usahanya dilakukan berdasarkan prinsip syariah, tetapi emiten tersebut tidak melakukan kegiatan usaha yang bertentangan dengan prinsip-prinsip syariah, seperti transaksi-transaksi yang termasuk perjudian, perdagangan yang dilarang syariah, jasa keuangan ribawi, jual beli mengandung ketidakpastian (gharar), memproduksi, mendistribusikan, memperdagangkan dan menyediakan barang atau jasa haram zatnya, serta melakukan transaksi yang mengandung unsur suap (risywah). Emiten juga diharuskan memenuhi rasio-rasio keuangan seperti: a). Total utang yang berbasis bunga dibandingkan dengan total aset tidak lebih dari $45 \%$, b). total pendapatan bunga dan pendapatan tidak halal lainnya dibandingkan dengan total pendapatan usaha (revenue) dan pendapatan lai-lain tidak lebih dari $10 \%$.

Saham atau efek syariah yang diakui di pasar modal Indonesia harus memenuhi kriteria seleksi saham syariah berdasarkan peraturan OJK Nomor 35/POJK.04/2017 tentang Kriteria dan Penerbitan Daftar Efek Syariah atau harus tercatat sebagai saham syariah oleh emiten atau perusahaan publik syariah berdasarkan peraturan OJK No.17/POJK.04/2015. Adapun perusahaan yang menerbitkan saham syariah ini disebut emiten syariah.

\section{B. Harga Saham}

Harga saham terbentuk melalui mekanisme penawaran dan permintaan yang muncul di pasar 
modal. Apabila suatu saham mengalami kelebihan permintaan maka harga saham cenderung naik, sebaliknya apabila kelebihan penawaran maka harga saham cenderung turun (Agus, 2008:70). Sedangkan harga saham syariah adalah nilai saham perusahaanperusahaan yang memiliki kriteria sesuai dengan prinsip syariah. Indeks komposit saham syariah yang tercatat di BEI disebut degan Indeks Saham Syariah Indonesia (ISSI) yang merupakan indikator dari kinerja pasar saham syariah di Indonesia. Konstituen ISSI diseleksi ulang sebanyak dua kali dalam setahun, setiap bulan Mei dan November. Oleh sebab itu, setiap periode seleksi, selalu ada saham yang keluar atau masuk menjadi konstituen ISSI.

Menurut Irham (2012:89) ada beberapa faktor yang mempengaruhi pergerakan harga saham atau indeks harga saham. Faktor tersebut dapat dapat dikategorikan pada faktor fundamental yang berasal dari lingkungan internal dan faktor kondisi ekonomi yang berasal dari lingkungan eksternal. Faktor-faktor tersebut antara lain sebagai berikut:

\section{Faktor Fundamental (Lingkungan Internal):}

a. Pengumuman tentang pemasaran, produksi, penjualan seperti pengiklanan, rincian kontrak, perubahan harga, penarikan produk baru, laporan produksi, laporan keamanan produk dan laporan penjualan.

b. Pengumuman laporan keuangan perusahaan, seperti peramalan laba sebelum akhir tahun fiskal dan setelah akhir tahun fiskal, Gross Profit Margin (GPM), Operating Profit Margin (OPM), Return On Assets (ROA), Return On Equity (ROE), Earneing Per Share (EPS) dan rasio keuangan lainnya.

\section{Faktor Kondisi Ekonomi (Lingkungan Eksternal)}

a. Pengumuman dari pemerintah, seperti perubahan suku bunga tabungan dan deposito, kurs valuta asing, inflasi serta berbagai regulasi dan deregulasi ekonomi yang dikeluarkan oleh pemerintah.

b. Pengumuman hukum (legal announcements), seperti tuntutan karyawan terhadap perusahaan atau terhadap manajer dan tuntutan perusahaan terhadap manajernya.

Pada penelitian ini, pergerakan harga saham diteliti dari faktor fundamental (faktor internal perusahaan) dengan mengambil beberapa rasio keuangan yang telah dipublikasikan berdasarkan laporan keuangan emiten syariah yang terdapat di BEI. Adapun rasio keuangan yang digunakan adalah dari rasio profitabilitas (ROE dan EPS) dan rasio solvabilitas (DER).

\section{ROE (Return on Equity)}

ROE termasuk rasio profitabilitas perusahaan, dimana profitabilitas adalah kemampuan perusahaan dalam menghasilkan laba. Menurut Sukmawati (2017:51) ROE adalah kemampuan perusahaan untuk menghasilkan laba bersih dari ekuitas (modal sendiri).

ROE yang tinggi akan menunjukkan bahwa perusahaan mampu mengelola modal yang dimilikinya secara baik untuk menghasilkan laba sehingga investor semakin tertarik menempatkan dananya pada perusahaan tersebut. Minat investor yang tinggi ini akan ikut menaikkan harga saham pada perusahaan tersebut. Rumus untuk perhitungan ROE adalah sebagai berikut:

$$
\text { ROE }=\frac{\text { Laba Bersih }}{\text { Total Ekuitas }}
$$

\section{DER (Debt to Equity Ratio)}

DER merupakan salah satu rasio solvabilitas perusahaan yang menunjukkan kemampuan perusahaan dalam memenuhi kewajiban jangka panjang. Menurut Darsono dan Anshari (2004:54) 
semakin tinggi rasio DER, semakin rendah pendanaan perusahaan yang disediakan oleh pemegang saham. Dari perspektif kemampuan membayar kewajiban jangka panjang, semakin rendah rasio akan semakin baik kemampuan perusahaan dalam membayar kewajiban jangka panjang.

Dapat disimpulkan DER yang tinggi akan menyebabkan investor cenderung menghindari investasi pada perusahaan tersebut sehingga ikut menurunkan harga sahamnya. Rumus untuk perhitungan DER adalah sebagai berikut:

$$
\text { DER }=\frac{\text { Total Kewajiban }}{\text { Total Ekuitas }}
$$

\section{E. EPS (Earning Per Share)}

EPS merupakan rasio profitabilitas perusahaan yang dilihat dari laba per lembar saham. EPS mengukur jumlah bersih laba yang terkandung di setiap lembar saham. EPS adalah rasio yang digunakan untuk menghitung laba atau keuntungan bersih yang diperoleh dari selembar saham Tryfino (2009:11).

Rasio EPS yang semakin tinggi menunjukkan kinerja perusahaan yang semakin baik sehingga daya tarik perusahaan tersebut pada investor semakin tinggi dan mempengaruhi harga saham menjadi meningkat. Rumus untuk perhitungan EPS:

$$
\text { EPS }=\frac{\text { Laba Saham Biasa }}{\text { Saham Biasa yang Beredar }}
$$

\section{F. Kerangka Konseptual}

Variabel dalam penelitian ini terdiri dari variabel independen (bebas) dan variabel dependen. Variabel independen $(\mathrm{X})$ adalah ROE $\left(\mathrm{X}_{1}\right)$, DER $\left(\mathrm{X}_{2}\right)$ dan EPS $\left(X_{3}\right)$, sedangkan harga saham syariah sebagai variabel dependen atau terikat (Y). Hubungan antara variabel $\mathrm{Y}$ dan variabel $\mathrm{X}$ tersebut adalah naik turunnya variabel $\mathrm{Y}$ dipengaruhi oleh perilaku kelompok $\mathrm{X}$, artinya apabila salah satu variabel bebas $\left(\mathrm{X}_{1}, \mathrm{X}_{2}, \mathrm{X}_{3}\right)$ berubah, maka akan mengakibatkan variabel terikat (Y) berubah.

Adapun kerangka konseptual dari penelitian ini sebagai berikut:

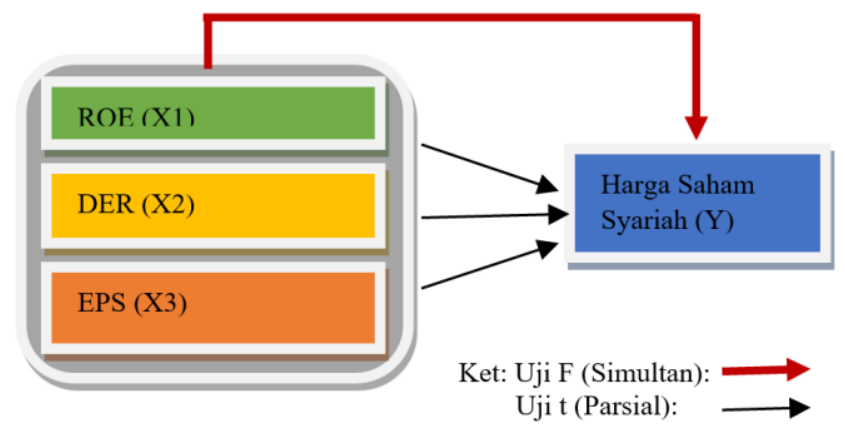

Gambar 2. Skema Kerangka Konseptual

\section{G. Hipotesis Penelitian}

Pada penelitian ini, penulis mencoba menguraikan jawaban sementara atas dasar kerangka konseptual yang telah dibuat sebelumnya. Menurut Sugiono (2009:11) hipotesis merupakan jawaban sementara terhadap rumusan masalah, di mana rumusan masalah peneliti telah dinyatakan dalam bentuk pernyataan. Hipotesis akan teruji apabila semua gejala yang timbul tidak bertentangan dengan hipotesis tersebut. Penyusunan hipotesis dalam penelitian ini dirumuskan sebagai berikut:

\section{Hipotesis secara simultan}

Ha = Diduga bahwa ROE, DER dan EPS secara simultan berpengaruh signifikan terhadap harga 
saham emiten syariah sektor barang konsumsi di BEI

\section{Hipotesis secara parsial}

$\mathrm{Ha}_{1}=$ Diduga bahwa ROE secara parsial berpengaruh signifikan terhadap harga saham emiten syariah sektor barang konsumsi di BEI

$\mathrm{Ha}_{2}=$ Diduga DER secara parsial berpengaruh signifikan terhadap harga saham emiten syariah sektor barang konsumsi di BEI

$\mathrm{Ha}_{3}=$ Diduga bahwa EPS secara parsial berpengaruh signifikan terhadap saham emiten syariah sektor barang konsumsi di BEI

\section{METODE}

\section{A. Jenis dan Sumber Data}

Penelitian ini merupakan penelitian kuantitatif dengan sumber data sekunder. Jenis data yang digunakan dalam penelitian ini bersifat data panel, yaitu gabungan antara data silang (cross section) dengan data runtut waktu (time series). Penelitian ini memilih perusahaan-perusahaan yang masuk dalam kriteria sampel sebanyak 24 perusahaan dengan beberapa periode waktu selama 5 tahun. Variabel penelitian adalah ROE, DER dan EPS sebagai variabel independen (bebas) dan harga saham syariah pada harga saham penutupan (closing price) sebagai variabel dependen (terikat).

Objek penelitian adalah emiten syariah sektor industri barang konsumsi di BEI periode 2013 sampai dengan 2017. Dalam penelitian ini penulis mengambil data sekunder dari Annual Report dan Summary perusahaan publik melalui sumber http://www.idx.co.id dan web resmi perusahaan emiten syariah sektor industri barang konsumsi sesuai dengan sampel yang telah ditentukan. Data yang digunakan seperti laporan posisi keuangan, laba rugi, laporan ekuitas dan laporan lainnya yang mendukung penelitian.

\section{B. Populasi dan Sampel}

Populasi dalam penelitian ini adalah semua emiten syariah sektor industri barang konsumsi yang tercatat di BEI periode 2013 sampai 2017. Daftar emiten yang menjadi populasi berjumlah 28 emiten syariah. Penelitian ini mengambil jenis sampel purposive sampling, yaitu anggota sampel yang dipilih berdasarkan pertimbangan tertentu baik berupa kemudahan dalam mendapat data yang diperlukan atau mudah untuk mengukurnya. Adapun kriteria yang ditentukan untuk sampel dalam penelitian ini adalah sebagai berikut:

1. Emiten syariah sektor industri barang konsumsi di BEI sebagai emiten selama periode penelitian

2. Laporan keuangan dipublikasikan selama periode penelitian

3. Perusahaan tersebut memiliki data ROE, DER dan EPS dan harga saham yang lengkap selama periode penelitian

Berdasarkan kriteria purposive sampling terpilih 24 perusahaan yang masuk dalam kriteria sampel pada penelitian ini. Dengan demikian total data penelitian pada sampel tersebut selama periode 2013 sampai dengan 2017 sebanyak 120 data.

\section{Teknik Analisis Data}

Teknik analisis data yang digunakan adalah analisis regresi linear berganda (multiple regretion analysis). Secara sistematis persamaan tersebut dapat ditulis dalam model matematis sebagai berikut:

$$
\mathbf{P}=a+\beta_{1} X_{1}+\beta_{2} X_{2}+\beta X_{3}+\varepsilon
$$

Keterangan:

$\mathrm{Y}=$ Harga saham 
$a=$ Konstanta (Intersep)

$\beta=$ Slope

$\mathrm{X}_{1}=$ Return On Equity

$\mathrm{X}_{2}=$ Debt to Equity Ratio

$\mathrm{X}_{3}=$ Earning Per Share

$\varepsilon \quad=$ Residual

Sebelum dilakukan pengujian hipotesis, terlebih dahulu harus dilakukan pengujian terhadap asumsiasumsi yang harus dipenuhi dalam metode Ordinary Least Square (OLS) sehingga parameter atau koefisien regresi tidak bias dan dapat mendeteksi keadaan yang sesungguhnya. Di dalam model regresi ini ada beberapa syarat pengujian yang harus dipenuhi agar model peramalan yang dibuat menjadi valid sebagai alat peramalan. Pengujian ini meliputi uji normalitas, uji multikolinieritas, uji autokorelasi, dan uji heteroskedastisitas. Apabila pengujian-pengujian tersebut dipenuhi maka model regresi linear yang dilakukan dikatakan Best Linear Unbias Estimation (BLUE).

\section{HASIL DAN PEMBAHASAN}

\section{A. Hasil}

1. Uji Asumsi Klasik

Tabel 1 Uji Normalitas Kolmogorov-Smirnov Test

\begin{tabular}{lll}
\hline $\mathrm{N}$ & $\begin{array}{l}\text { Nilai Asymp. Sig (2 } \\
\text { tailed })\end{array}$ & Keterangan \\
\hline 120 & 0,76 & Data Normal
\end{tabular}

Sumber: Hasil Output SPSS Versi 18 (2019)
Hasil uji normalitas pada tabel 1 menunjukkan bahwa data residual terdistribusi normal karena nilai Sig. 0,76>0,05 sehingga model regresi pada penelitian ini telah memenuhi asusumsi normalitas.

Tabel 2 Uji Multikolinieritas

\begin{tabular}{lccl}
\hline Variabel & Tolerance & VIF & Keterangan \\
\hline ROE & 0,661 & 1,514 & Tidak terjadi \\
DER & 0,687 & 1,456 & Tidak terjadi \\
EPS & 0,879 & 1,138 & Tidak terjadi
\end{tabular}

Sumber: Hasil Output SPSS Versi 18 (2019)

Hasil uji multikolinieritas pada Tabel 2 menunjukkan bahwa untuk semua variabel independen nilai tolerance $>0,10$ dan VIF $<10$ sehingga dapat disimpulkan tidak terjadi masalah multikolineritas dalam penelitian ini.

Tabel 3 Uji Autokorelasi

\begin{tabular}{lc}
\hline Nilai Durbin-Watson & Keterangan \\
\hline 1.801 & Tidak terjadi \\
\hline Sumber: Hasil Output SPSS Versi $18(2019)$
\end{tabular}

Hasil uji autokorelasi pada tabel 3 menunjukkan bahwa nilai Durbin-Watson (d) 1,801. Berdasarkanketentuan dasar pengambilan keputusan dalam uji autokorelasi Durbin Watson menurut Cornelius (2010:139) jika diketahui nilai d berada diantara $1,65<\mathrm{DW}<2,35$ maka hasil uji tersebut tidak terjadi autokorelasi sehingga dapat disimpulkan bahwa model regresi dalam penelitian ini tidak terdapat autokorelasi karena nilai d berada diantara $1,65<1,80<2,35$. 


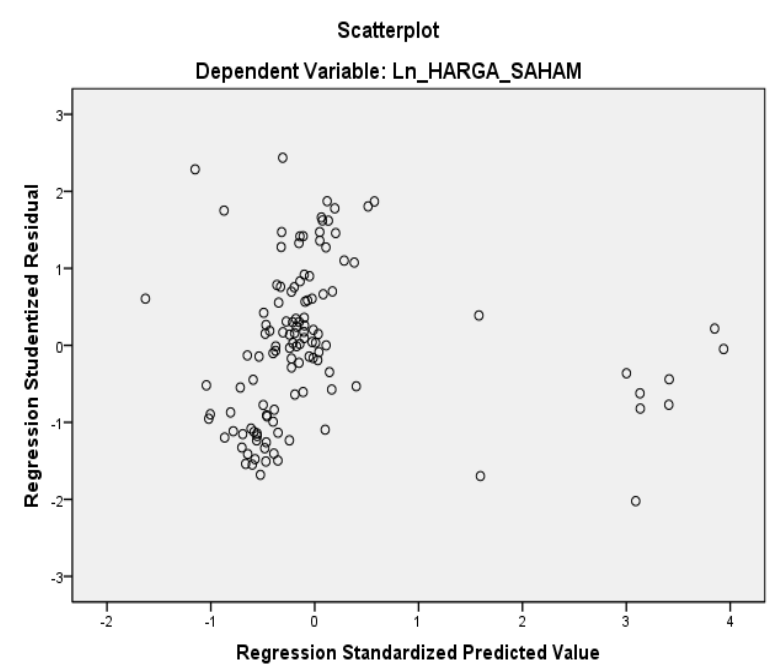

Gambar 2. Uji Heterokedastisitas Sumber: Hasil Output SPSS Versi 18 (2019)

Gambar 2 menunjukkan bahwa plot data menyebar di atas dan di bawah atau di sekitar angka 0 dan tidak mengumpul hanya di atas dan di bawah saja pada sumbu Regression Studentized Residual dan penyebaran titik-titik data tidak membentuk pola tertentu. Hal ini menyimpulkan bahwa model regresi yang terbentuk dinyatakan tidak terjadi gejala heterokedastisitas.

\section{Pengujian Hipotesi}

Tabel 4 Hasil Uji Simultan dengan F-Test

\begin{tabular}{lccccc}
\multicolumn{7}{c}{ ANOVA $^{\text {a }}$} \\
\hline \multicolumn{1}{c}{ Model } & $\begin{array}{c}\text { Sum } \\
\text { of } \\
\text { Squares }\end{array}$ & Df & $\begin{array}{c}\text { Mean } \\
\text { Square }\end{array}$ & F & Sig. \\
\hline Regression & 165,965 & 3 & 55,322 & 36,933 & $0,000^{\text {a }}$ \\
1 Residual & 173,758 & 116 & 1,498 & & \\
Total & 339,724 & 119 & & &
\end{tabular}

Sumber: Hasil Output SPSS Versi 18 (2019)
Pengaruh ROE, DER, dan EPS Terhadap

Harga Saham pada Emiten Syariah Sektor

Barang Konsumsi di BEI

Berdasarkan Tabel 4 dapat diketahui bahwa nilai $F_{\text {hitung }}$ sebesar 36,933, dan $F_{\text {tabel }}$ sebesar 2,68 yang diperoleh dari tabel distribusi $\mathrm{F}$ untuk $\alpha 0,05$ (level of significance) dengan $\mathrm{df} 1=3$ dan $\mathrm{df} 2=116$ sehingga nilai $F_{\text {hitung }} 36,933>F_{\text {tabel }} 2,68$. Selain itu, nilai signifikansi $\mathrm{F}$ yang diperoleh dari tabel ANOVA diketahui lebih kecil dari signifikan taraf nyata (level of significance $) \alpha=0,05(0,000<0,05)$ sehingga dapat disimpulkan hipotesis $\mathrm{H}_{\mathrm{a}}$ diterima yang artinya $\mathrm{ROE}$, DER dan EPS secara simultan berpengaruh signifikan terhadap harga saham emiten syariah sektor barang konsumsi di BEI.

Tabel 5 Uji Parsial dengan t-Test

\begin{tabular}{|c|c|c|c|c|c|}
\hline \multicolumn{6}{|c|}{ Coefficients $^{a}$} \\
\hline \multirow[t]{2}{*}{ Model } & \multicolumn{2}{|c|}{$\begin{array}{l}\text { Unstandardized } \\
\text { Coefficients }\end{array}$} & $\begin{array}{l}\text { Standardized } \\
\text { Coefficients }\end{array}$ & \multirow[b]{2}{*}{$\mathrm{t}$} & \multirow[b]{2}{*}{ Sig. } \\
\hline & $\mathrm{B}$ & $\begin{array}{l}\text { Std. } \\
\text { Error }\end{array}$ & Beta & & \\
\hline (Constant) & 6,790 & 0,223 & & 30,462 & 0,000 \\
\hline ROE & 0,035 & 0,005 & 0,532 & 6,517 & 0,000 \\
\hline DER & $-0,236$ & 0,260 & $-0,073$ & $-0,908$ & 0,366 \\
\hline EPS & 0,001 & 0,000 & 0,377 & 5,329 & 0,000 \\
\hline
\end{tabular}

Sumber: Hasil Output SPSS Versi 18 (2019)

Nilai $t_{\text {tabel }} \alpha=0,05$ adalah sebesar 1,658 yang diperoleh dari $\mathrm{t}_{\text {tabel }}$ dengan derajat bebas $\mathrm{df}=\mathrm{n}-\mathrm{k}-1$ atau $120-3-1=116$. Sehingga pada hasil masingmasing variabel independen tersebut adalah sebagai berikut:

1. Hasil pengujian hipotesis ROE diperoleh nilai $t_{\text {hitung }}$ sebesar 6,517 (arah positif), angka tersebut menunjukkan bahwa nilai thitung $(6,517)$ lebih besar daripada $t_{\text {tabel }}(1,658)$ dan $\mathrm{p}$-value $(0,000)$ lebih kecil daripada a $(0,05)$ sehingga $\mathrm{H}_{\mathrm{a} 1}$ diterima. Dengan demikian dapat disimpulkan bahwa ROE secara parsial berpengaruh positif dan signifikan terhadap harga saham.

2. Hasil pengujian hipotesis DER diperoleh nilai $\mathrm{t}_{\text {hitung }}$ sebesar $-0,908$ (arah negatif), angka tersebut 
Pengaruh ROE, DER, dan EPS Terhadap

Harga Saham pada Emiten Syariah Sektor

Barang Konsumsi di BEI

menunjukkan bahwa nilai thitung $(-0,908)$ lebih kecil daripada $t_{\text {tabel }}(1,658)$ dan p-value $(0,366)$ lebih kecil daripada a $(0,05)$ sehingga $\mathrm{H}_{\mathrm{a} 2}$ ditolak. Dengan demikian dapat disimpulkan bahwa DER secara parsial tidak memiliki pengaruh signifikan terhadap harga saham.

3. Hasil pengujian hipotesis EPS diperoleh nilai $t_{\text {hitung }}$ sebesar 5,329 (arah positif), angka tersebut menunjukkan bahwa nilai thitung $(5,329)$ lebih besar daripada $t_{\text {tabel }}(1,658)$ dan p-value $(0,000)$ lebih kecil daripada a $(0,05)$ sehingga $\mathrm{H}_{\mathrm{a} 3}$ diterima. Dengan demikian dapat disimpulkan bahwa EPS secara parsial berpengaruh positif dan signifikan terhadap harga saham.

\section{Koefisien Determinasi}

Tabel 6 Hasil Analisis Koefisien Determinasi R $^{2}$

\begin{tabular}{cccccc}
\hline \multicolumn{7}{c}{ Model Summary $^{\mathbf{b}}$} \\
\hline Model & $\mathrm{R}$ & $\mathrm{R}$ & $\begin{array}{c}\text { Adjusted } \\
\mathrm{R} \\
\text { Square } \\
\text { Square }\end{array}$ & $\begin{array}{c}\text { Std. } \\
\text { Error of } \\
\text { the } \\
\text { Estimate }\end{array}$ & $\begin{array}{c}\text { Durbin- } \\
\text { Watson }\end{array}$ \\
& & & & & \\
1 & $0,699^{\mathrm{a}}$ & 0,489 & 0,475 & 1,22389 & 1,801
\end{tabular}

Sumber: Hasil Output SPSS Versi 18 (2019)

Berdasarkan tabel 6 diperoleh nilai $\mathrm{R}^{2}$ (adjusted $R$ Square) sebesar 0,489 atau (48,9\%). Hal ini menunjukkan bahwa presentase sumbangan pengaruh variabel independen (ROE, DER dan EPS) sebesar $48,9 \%$, sedangkan $51,1 \%$ dipengaruhi oleh faktor lain yang tidak diteliti dalam penelitian ini. Selain itu, angka koefisien korelasi (R) 0,70 sampai mendekati 1,00 menunjukkan keterkaitan hubungan yang tinggi, 0,40 sampai mendekati 0,70 menunjukkan keterkaitan yang sedang, dan 0,20 sampai 0,40 menunjukkan keterkaitan hubungan yang rendah. Dengan demikian, nilai $\mathrm{R}$ yang diperoleh pada penelitian adalah sebesar 0,699 atau $(69,9 \%)$. Hal ini menunjukkan hubungan yang sedang antara variabel independen dengan variabel dependen, karena koefisien korelasi di atas 0,05 .

\section{Hasil Uji Analisis Regresi Linier Berganda}

Tabel 7 Hasil Uji Analisis Regresi Linier Berganda

\begin{tabular}{|c|c|c|c|c|c|}
\hline \multicolumn{6}{|c|}{ Coefficients $^{\mathbf{a}}$} \\
\hline \multirow[t]{3}{*}{ Model } & \multirow{2}{*}{\multicolumn{2}{|c|}{$\begin{array}{c}\text { Unstandardized } \\
\text { Coefficients }\end{array}$}} & \multirow{2}{*}{$\begin{array}{l}\text { Standardized } \\
\text { Coefficients }\end{array}$} & \multirow[b]{3}{*}{$\mathrm{T}$} & \multirow[b]{3}{*}{ Sig. } \\
\hline & & & & & \\
\hline & B & Std. Error & Beta & & \\
\hline (Constant) & 6,790 & 0,223 & & 30,462 & 0,000 \\
\hline ROE & 0,035 & 0,005 & 0,532 & 6,517 & 0,000 \\
\hline DER & $-0,236$ & 0,260 & $-0,073$ & $-0,908$ & 0,366 \\
\hline EPS & 0,001 & 0,000 & 0,377 & 5,329 & 0,000 \\
\hline
\end{tabular}

Sumber: Hasil Output SPSS Versi 18 (2019)

Berdasarkan tabel 7, maka model persamaan regresi linier berganda untuk penelitian ini adalah sebagai berikut:

Harga Saham $=6,790+0,035$ ROE $-0,236$ DER $+0,001$ EPS

Interpretasi dari persamaan model regresi linier berganda di atas adalah sebagai berikut:

1. Nilai Konstanta $(\alpha)$ model persamaan regresi adalah sebesar 6,790. Artinya jika variabel independen (ROE, DER dan EPS) bernilai nol, maka rata-rata harga saham pada sektor industri barang konsumsi di BEI periode 2013-2017 adalah sebesar 6,790 satuan.

2. Nilai koefisien regresi $\operatorname{ROE}\left(\beta_{1}\right)$ adalah sebesar 0,035 . Hal ini menunjukkan terdapat hubungan positif antara ROE dengan harga saham. Dengan 
Pengaruh ROE, DER, dan EPS Terhadap

Harga Saham pada Emiten Syariah Sektor

Barang Konsumsi di BEI

demikian dapat disimpulkan bahwa setiap peningkatan ROE sebesar 1\%, maka harga saham akan mengalami peningkatan $0,035 \%$, dengan catatan variabel bebas lain dalam penelitian ini tidak mengalami perubahan atau dianggap tetap (cateris paribus).

3. Nilai koefisien regresi DER $\left(\beta_{2}\right)$ adalah sebesar 2,36. Hal ini menjelaskan bahwa terdapat hubungan negatif antara DER dengan harga saham. Dapat diartikan bahwa setiap kenaikan 1\% DER maka harga saham akan mengalami penurunan $2,36 \%$, dengan catatan variabel bebas dalam penelitian ini dianggap tetap.

4. Nilai koefisien regersi EPS $\left(\beta_{3}\right)$ adalah sebesar 0,001. Hal ini menunjukkan bahwa terdapat hubungan positif antara EPS dan harga saham. Dengan demikian dapat disimpulkan bahwa setiap peningkatan EPS 1\%, maka harga saham akan mengalami kenaikan sebesar $0,001 \%$, dengan catatan variabel lain tidak mengalami perubahan.

\section{B. Pembahasan}

1. Pengaruh ROE, DER dan EPS secara Simultan terhadap harga saham eminten syariah sektor barang konsumsi di BEI.

Berdasarkan uji simultan F-test yang telah dilakukan, diperoleh nilai $F_{\text {hitung }}$ sebesar 36,933, dan $F_{\text {tabel }}$ sebesar 2,68 dengan nilai signifikansi yang diperoleh lebih kecil dari signifikan taraf nyata (level of significance $) \alpha=0,05(0,000<0,05)$ sehingga dapat disimpulkan hipotesis $\mathrm{H}_{\mathrm{a}}$ diterima yang artinya ROE, DER dan EPS secara simultan berpengaruh signifikan terhadap harga saham emiten syariah sektor barang konsumsi di BEI periode 2013-2017.

\section{Pengaruh ROE secara Parsial terhadap harga saham emiten syariah sektor barang konsumsi di BEI}

Berdasarkan hasil uji parsial atau t-test yang telah dilakukan, diperoleh nilai $t_{\text {hitung }}>t_{\text {tabel }}(6,517>1,658)$ dengan nilai signifikasi yang diperoleh lebih kecil dari signifikasi taraf nyata $(0,000<0,05)$, sehingga dapat diartikan adanya hubungan yang kuat antara ROE terhadap harga saham, selain iu terdapat hubungan arah positif antara variabel tersebut. Hal ini dapat dibuktikan dengan nilai koefisien regersi ROE yang diperoleh 0,035 pada arah positif, sehingga dapat dinyatakan bahwa hipotesis $\mathrm{Ha}_{1}$ diterima yang artinya ROE secara parsial berpengaruh positif dan signifikan terhadap harga saham.

Kesimpulannya adalah apabila nilai ROE mengalami peningkatan maka akan diikuti dengan peningkatan harga saham. Hasil penelitian ini mendukung teori yang dikemukakan Kasmir (2012), yaitu semakin tinggi ROE, perusahaan semakin baik sehingga pemegang saham dapat memperoleh tingkat pengembalian yang lebih tinggi dibandingkan ratarata industri dan menunjukkan kondisi perusahaan juga baik. Hal ini didukung oleh penelitian terdahulu yang dilakukan Valintino dan Sularto (2013).

\section{Pengaruh DER secara Parsial terhadap harga saham emiten syariah sektor barang konsumsi di BEI}

Berdasarkan hasil uji parsial atau t-test yang telah dilakukan, diperoleh $t_{\text {hitung }}>\mathrm{t}_{\text {tabel }}(-0,908<1,658)$ dengan nilai signifikansi yang diperoleh lebih kecil dari signifikansi taraf nyata $(0,000<0,05)$, sehingga dapat diartikan DER tidak berpengaruh signifikan terhadap harga saham. Selain itu, terdapat arah hubungan negatif antara variabel tersebut, hal ini 
dibuktikan dengan nilai koefisien regresi DER $(-2,36)$ yang diperoleh pada arah negatif, sehingga dapat dinyatakan bahwa hipotesis $\mathrm{Ha}_{2}$ ditolak yang artinya DER secara parsial berpengaruh negatif dan tidak signifikan terhadap harga saham.

Kesimpulannya adalah apabila DER mengalami peningkatan makan akan menurunkan harga saham. Hasil penelitian ini mendukung teori yang dikemukakan Agus (2008) yang menyatakan bahwa hubungan DER dan harga saham terletak pada besarnya rasio. Semakin tinggi DER maka semakin besar risiko yang dihadapi, dan investor akan meminta tingkat keuntungan yang semakin tinggi. Rasio yang tinggi juga menunjukkan proporsi modal sendiri yang rendah untuk membiayai aktiva. Namun, umumnya investor cenderung menghindari saham-saham yang memiliki DER yang tinggi.

\section{Pengaruh EPS secara Parsial terhadap harga saham emiten syariah sektor barang konsumsi di BEI}

Berdasarkan hasil uji parsial atau t-test yang telah dilakukan, diperoleh nilai $t_{\text {hitung }}>t_{\text {tabel }}(5,329>1,658)$ dengan nilai signifikasi yang diperoleh lebih kecil dari signifikasi taraf nyata $(0,000<0,05)$, sehingga dapat diartikan adanya hubungan yang kuat antara ROE terhadap harga saham, selain iu terdapat hubungan arah positif antara variabel tersebut. Hal ini dapat dibuktikan dengan nilai koefisien regresi EPS yang diperoleh 0,001 pada arah positif, sehingga dapat dinyatakan bahwa hipotesis $\mathrm{Ha}_{3}$ diterima yang artinya EPS secara parsial berpengaruh positif dan signifikan terhadap harga saham.

Kesimpulannya adalah apabila nilai EPS mengalami peningkatan maka akan diikuti dengan peningkatan harga saham. Hasil penelitian ini sesuai dengan Hanafi (2009:73) bahwa pemegang saham tertarik degan EPS yang dilaporkan perusahaan. EPS yang tinggi merupakan sinyal positif bagi investor untuk membeli dan mempertahankan saham dengan harapan untuk memperoleh deviden atau capital gain.

\section{KESIMPULAN}

Berdasarkan hasil pengolahan data dari penelitian ini dapat diperoleh kesimpulan sebagai berikut:

1. Hasil uji determinan $\left(\mathrm{R}^{2}\right)$, diperoleh nilai $\mathrm{R}^{2}$ sebesar 0,489 atau 48,9\% menunjukkan bahwa persentase sumbangan pengaruh ROE, DER dan EPS terhadap harga saham sebesar 48,9\%. Sedangkan sisanya sebesar $51,1 \%$ adalah dipengaruhi oleh faktor lain yang tidak diteliti dalam penelitian ini

2. Secara simultan ROE, DER dan EPS berpengaruh signifikan terhadap saham emiten syariah sektor barang konsumsi di BEI.

3. Secara parsial, ROE dan EPS berpengaruh signifikan terhadap harga saham, sedangkan DER tidak memiliki pengaruh terhadap harga saham emiten syariah sektor barang konsumsi di BEI.

\section{REFERENSI}

Abdullah, H., Soedjatmiko and Hartati, A. (2016) 'Pengaruh EPS, DER, PER, ROA dan ROE Terhadap Harga Saham Pada Perusahaan Tambang Yang Terdaftar di BEI Untuk Periode 2011-2013', DINAMIKA EKONOMI Jurnal Ekonomi dan Bisnis, 9(1), pp. 1-20.

Agus, S. (2008) Manajemen Keuangan Teori dan Aplikasi Edisi Empat. Yogyakarta: BPFE.

Alipudin, A. (2016) 'Pengaruh EPS, ROE, ROA dan 
DER Terhadap Harga Saham Pada Perusahaan Sub Sektor Semen Yang Terdaftar di BEI', JIAFE (Jurnal Ilmiah Akuntansi Fakultas Ekonomi), 2(1), pp. 1-22.

Cornelius, T. (2010) Step By Step SPSS 18 Analisis Data Statistik. Yogyakarta: Andi Offset.

Darsono and Ashari (2004) Pedoman Praktis Memahami Laporan Keuangan. Yogyakarta: CV Andi Offset.

Eduardus, T. (2017) Pasar Modal Manajemen Portofolio \& Investasi. Yogyakarta: PT Kanisius.

Hanafi, M. M. (2009) Analisis Laporan Keuangan. Yogyakarta: UPP STIM YKPN.

Irham, F. (2012) Analisis Laporan Keuangan. Bandung: Alfabeta.

Kasmir (2012) Analisis Laporan Keuangan. Jakarta: PT Raja Grafindo.

OJK, T. (2015) Buku Saku Otoritas Jasa Keuangan”, Edisi Kedua.

Sugiono (2009) Metode Penelitian Kuantitatif, Kualitatif dan $R \& D$. Bandung: Alfabeta.

Sukmawati, S. (2017) Pengantar Pemodelan Keuangan dan Analisis Pasar Modal. Yogyakarta: Andi.

Supadi, DBP dan Amin, M.N "Pengaruh Faktor Fundamental dan Risiko Sistematis Terhadap Return Saham Syariah", Media Riset Akuntansi, Auditing dan Informasi, Vol.12, 2016.

Tryfino (2009) Cara Cerdas Berinvestasi Saham. Jakarta: Transmedia Pustaka.

Utami, M.R dan Darmawan, A "Pengaruh EPS, ROE, ROA dan DER Terhadap Harga Saham Pada Indeks Saham Syariah Indonesia", Journal of Applied Managerial Accounting, Vol.2, pp. 206-218, 2018.

Valintino, R. and Sularto, L. (2013) 'Pengaruh Return On Asset, Current Ratio, Return On Equity, Debt To Equity Ratio, dan Earning Per Share Terhadap Harga Saham Perusahaan Manufaktur Sektor Industri barang Konsumsi di BEI', in. Bandung: Proceeding PESAT (Psikologi, Ekonomi, Sastra, Arsitektur \& Teknik Sipil), pp. 195-202.

http://www.ojk.go.id, "Perkembangan Pasar Modal Syariah 2016", p. 5, diunduh tanggl 15 November 2018.

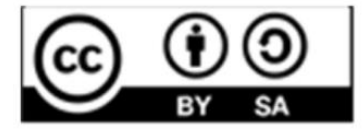

Copyright (C) 2020 Vocatech: Vocational Education and Technology Journal This works is licensed under a Creative Common Attribution-ShareAlike 4.0 